\title{
META-ANALYSIS THE EFFECT BACK SCHOOL PROGRAM TO REDUCE PAIN IN PATIENTS WITH CHRONIC NON-SPECIFIC LOW BACK PAIN
}

\author{
Sima Asmara Dewa Marya Mahardika Putri, Nanda Agustian Simatupang
}

\author{
Masters Program in Public Health, Universitas Sebelas Maret
}

\begin{abstract}
Background: Most low back pain is the result of an injury, such as muscle sprains or strains due to sudden movements or poor body mechanics while lifting heavy objects, or the result of certain diseases. Back school program is an educational and training program with lessons given to patients for treating or preventing low back pain. This study aimed to examine the effect back school program to reduce pain in patients with chronic non-specific low back pain.

Subjects and Method: A systematic review and meta analysis study was conducted by following PRISMA flow diagram. The study collected articles from PubMed, Science Direct, Google Schoolar, and PEDro databases. Keywords used (LBP OR "Low Back Pain") AND ("Back School" OR "Back School Program") AND ("randomized controlled trial" OR RCT). The inclusion criteria were (1) full text, (2) Randomized Controlled Trial (RCT), (3) published from 2010 to 2020, (4) reported Mean and Standard Deviation, (5) intervention was back school program, (6) study subjects were at age 1865 years, and (7) experienced non-specific chronic low back pain without radicular pain. The articles that met the criteria were assessed using RevMan 5.3 application program.

Results: A meta-analysis from 9 studies showed that back school program reduced pain in patients with non-specific chronic low back pain 0.44 times than other intervention or non-intervention $(\mathrm{SMD}=-0.44 ; 95 \% \mathrm{CI}=-1.19$ to $0.31 ; \mathrm{p}=0.25)$.

Conclusion: Back school program reduced pain in patients with non-specific chronic low back pain.

Keywords: back school program, low back pain, meta-analysis

Correspondence:

Sima Asmara Dewa Marya Mahardika Putri. Masters Program in Public Health. Universitas Sebelas Maret. Jl. Ir. Sutami 36A, Surakarta 57126, Central Java. Email: simaasmara@gmail.com. Mobile: 082140354882.
\end{abstract}

The $8^{\text {th }}$ International Conference on Public Health Solo, Indonesia, November 17-18, 2021 | 22 https://doi.org/10.26911/AB.Epidemiology.ICPH.08.2021.02 